\title{
Pre-harvest Desiccation: Productivity and Physical and Physiological Inferences on Soybean Seeds During Storage
}

\author{
Elias Zanatta ${ }^{1}$, Vinícius J. Szareski ${ }^{1}$, Ivan R. Carvalho ${ }^{1}$, Felipe Koch ${ }^{1}$, João R. Pimentel ${ }^{1}$, Cristian Troyjack ${ }^{1}$, \\ Simone M. Dellagostin ${ }^{1}$, Gustavo H. Demari ${ }^{1}$, Francine Lautenchleger ${ }^{2}$, Velci Q. de Souza ${ }^{3}$, \\ Emanuela G. Martinazzo ${ }^{4}$, Francisco A. Villela ${ }^{1}$, Tiago Pedó ${ }^{1} \&$ Tiago Z. Aumonde ${ }^{1}$ \\ ${ }^{1}$ Universidade Federal de Pelotas, Campus Capão do Leão, RS, Brazil \\ ${ }^{2}$ Universidade Estadual de Maringá, PR, Brazil \\ ${ }^{3}$ Universidade Federal do Pampa, RS, Brazil \\ ${ }^{4}$ Universidade Federal do Rio Grande, RG, Brazil \\ Correspondence: Vinícius J. Szareski, Universidade Federal de Pelotas, Campus Capão do Leão, CEP 96050-500, \\ Capão do Leão, RS, Brazil. E-mail: viniciusszareski@gmail.com \\ Ivan R. Carvalho, Universidade Federal de Pelotas, Campus Capão do Leão, CEP 96050-500, Capão do Leão, \\ RS, Brazil. E-mail: carvalhoirc@gmail.com
}

Received: January 11, $2018 \quad$ Accepted: March 7, $2018 \quad$ Online Published: May 15, 2018
doi:10.5539/jas.v10n6p354

\begin{abstract}
The objective of this research is to define which soybean phenological stage is adequate to promote pre-harvest desiccation and to measure the effects of this procedure on the physical and physiological attributes of soybean seeds throughout storage. The experiment was carried out at Fazenda Santa Bárbara da Boa Vista located in the municipality of Cabeceiras, Goiás, Brazil. The experimental design was the randomized blocks arranged in a factorial scheme being five phenological stages of soybean development where desiccant was applied (R5.5, R6.0, R7.1, R7.3 and R8.3) $\times$ five post-harvest storage times $(0,40,80,120,160$ days), arranged in four replicates. The measured characters were: Productivity, Mass of one thousand seeds, Retention of sieves $5.5 \mathrm{~mm}$, $6.0 \mathrm{~mm}$ and $6.5 \mathrm{~mm}$, Germination, Accelerated aging and Field emergence. The application of the Paraquat molecule in soybean plants in the phenological stages R5.5 and R6.0 compromises the physical attributes, mass of a thousand seeds and productivity. The germination and vigor of the soybean seeds are adversely affected due to the early desiccation of the plants, and these effects are potentiated throughout the seed storage.
\end{abstract}

Keywords: Glicine max L., storage, seed quality

\section{Introduction}

Brazil occupies the second position in the world production of soybean, being inferior only to the United States. In the agricultural crop of 2016/2017 the country showed production of more than 114 million tons of grains in a sown area of more than 33 million hectares, with an average yield of 3.4 tons of grains per hectare (Conab, 2017).

However, the production of soybean seeds is based on the premise of anticipating the harvest as close as possible to the physiological maturity, at which point, a higher probability of revealing seeds with the highest accumulation of dry matter, germination and vigor is obtained. However, the physiological maturity and the harvesting point do not coincide, because in the physiological maturity the seeds are humid and the plants show morphological structures that still vegetate, a fact that has negative implications for mechanized harvesting operations (Peske et al., 2012).

The search for the production of seeds with high performance becomes a challenge, especially with regard to the obtaining of seeds with high added vigor, in this context, it is sought to reduce to the maximum the period of exposure of the seeds to adverse environmental conditions, such as the oscillations of relative humidity and air temperature, precipitation, diseases and insect-plague attack (Szareski et al., 2016; Follmann et al., 2017). Linked to these factors, the delay in the harvest of the seeds becomes enough to reduce the germination and the vigor of the seeds (Sedyama, 2013; Forti et al., 2013; Kehl et al., 2016; Rigo et al., 2018). 
In this scenario, seed producers can make use of desiccant products, which enable foliar abscission of the plants, as well as the early harvesting of the seeds in the field, this allows to anticipate, plan and obtain greater efficiency in the harvesting practices, seeking homogeneous crops, free of undesirable plants, lower number of green plants and high quality seeds (Castro et al., 2016; Vargas et al., 2018). In the current agricultural context the main herbicide used in soybean desiccation operations is composed of the paraquat molecule that consists of the contact action, non selective, with low translocation in the plant, low persistence in the soil and total control of the vegetation.

Some researches have been carried out to highlight the effects of desiccants on preharvest and their reflexes on the final quality of soybean seeds; however, many are the disturbing factors in the expression of herbicide effects, such as climatic conditions and the phenological stage of the plants at the time of application, the best conditions are sought so that the seeds of high physical and physiological quality can be obtained not only at the time of harvest, but also during their storage.

For the soybean crop, the objective is to use this practice to anticipate the harvest and obtain satisfactory gains to the seed-multiplying companies, since the pre-harvest desiccation will allow the reduction in the number of days between the physiological maturity and the harvesting point of the seeds, without compromising the physical and physiological attributes of the seeds (Albretch et al., 2012; Guimarães et al., 2012; Lamego et al., 2013; Delgado et al., 2015; Pereira et al., 2015a; Silva-Xavier et al., 2015; Pereira et al., 2015b; Szareski et al., 2017; Mathias et al., 2017).

In view of the need to clarify the most appropriate moment to perform the pre-harvest desiccation and its effects on the main physical and physiological attributes of soybean, this work had as objective to define which soybean phenological stage is adequate to promote pre-harvest desiccation and to measure the effects of this procedure on the physical and physiological attributes of soybean seeds throughout storage.

\section{Material and Methods}

The experiment was carried out at Fazenda Santa Bárbara da Boa Vista located in the municipality of Cabeceiras, Goiás, Brazil. The experimental field is located under the geographical coordinates with latitude of $15^{\circ} 42^{\prime} 26^{\prime \prime} \mathrm{S}$ and longitude 53 $49^{\prime} 46^{\prime \prime} \mathrm{W}$ and 924 meters of altitude. The region reveals average rainfall of $1300 \mathrm{~mm}$ and average annual temperature of $23.5^{\circ} \mathrm{C}$, the soil is characterized as a Red Latosol.

The experimental design was the randomized blocks arranged in a factorial scheme being five phenological stages of soybean development where desiccant was applied (R5.5, R6.0, R7.1, R7.3 and R8.3) $\times$ five post-harvest storage times $(0,40,80,120,160$ days $)$, arranged in four replicates.

Desiccations were performed with paraquat active ingredient desiccant at a dose of 400 grams of active ingredient per hectare. The experimental units consisted of 10 lines with 15 meters in length and spaced with 0.5 meters, totaling $75 \mathrm{~m}^{2}$. The cultivar used was P98Y12 RR, characterized by an indeterminate growth habit, where the sowing was performed in the first half of October in the population density of 180 thousand plants per hectare.

The nutritional management consisted of $250 \mathrm{~kg} \mathrm{ha}^{-1}$ of NPK in the formulation 05-37-00 at the sowing base and $120 \mathrm{~kg} \mathrm{ha}^{-1}$ of potassium chloride $\left(60 \% \mathrm{~K}_{2} \mathrm{O}\right)$ applied 30 days before sowing. The seeds were harvested according to the maturation of each treatment and the seeds were then stored at $180{ }^{\circ} \mathrm{C}$ with $60 \%$ relative humidity. The measured characters were:

Productivity: this character was measured in the useful area of each experimental unit, the plants were harvested and threshed, afterwards the seed mass was adjusted to the moisture content of $12.5 \%$, the results were expressed in $\mathrm{kg} \mathrm{ha}^{-1}$.

Mass of one thousand seeds: obtained through eight subsamples with 100 seeds following the Rules for Seed Analysis (Brasil, 2009), results expressed in grams (g).

Retention of sieves: This test was performed with 500 grams of sample, being subdivided into two replicates with 250 grams per treatment effect. Measurements of sieve retention of $5.5 \mathrm{~mm}, 6.0 \mathrm{~mm}$ and $6.5 \mathrm{~mm}$ were performed, the results were expressed in grams $(\mathrm{g})$.

Germination: measured by means of 400 seeds for each treatment, these being seeded in roll of germitest paper, moistened with volume of water 2.5 times the mass of the dry substrate and kept in germination chamber B.O.D. type, at a temperature of $25^{\circ} \mathrm{C}$, with photoperiod of 12 hours. The counting was performed on the eighth day after sowing (Brasil, 2009), results expressed as a percentage of normal seedlings. 
Accelerated aging: obtained through the use of gerbox plastic boxes in the dimensions $(11 \times 11 \times 3 \mathrm{~cm})$, the relative humidity inside these was obtained by the addition of $40 \mathrm{ml}$ of water (environment with $75 \%$ R.H.). Samples from each treatment were distributed so as to form a single layer taking the entire surface of the metal screen suspended inside the carton. This procedure was conducted at a temperature of $41{ }^{\circ} \mathrm{C}$ where the seeds remained for 72 hours inside the B.O.D. chamber (Marcos Filho et al., 1999). Afterwards, the germination test was carried out (Brasil, 2009), and the counts were carried out after five days of sowing, results in percentage.

Field emergence: measured in four subsamples containing 100 seeds per treatment, the sowing was performed at the standard depth of three centimeters and the seeds were arranged in lines of three meters in length $\times 0.45$ meters between rows. The measurement was done at 21 days after sowing, results expressed as percentage.

The data were submitted to analysis of variance at $5 \%$ of probability by the $\mathrm{F}$ test, where the assumptions were verified. In order to show the general performance of each measured character, a descriptive analysis was performed, and the magnitudes were evidenced by means of graphs. Subsequently, the diagnosis of the interaction among phenological stages of soybean development was carried out, where desiccant $\mathrm{x}$ times of storage after harvest were applied.

The characters that showed interaction were dismantled to the simple effects for the qualitative variation factor (phenological stages of soybean development where desiccant was applied). In the same way, the quantitative factor was submitted (storage times after harvest) to the linear regression, where the highest significant degree of the polynomial was tested through the t-test at $5 \%$ of probability, and this procedure was performed for each level of the qualitative variation factor. The characters that did not show interaction were subjected to dismemberment by the main effects through the Tukey test at $5 \%$ of probability, and the quantitative factor was submitted to a general linear regression.

\section{Results and Discussion}

In order to understand the expression of the characters of importance productivity (Figure 1a), mass of one thousand seeds (Figure 1b), retention of sieve $5.0 \mathrm{~mm}$ (Figure 1c), retention of sieve $5.5 \mathrm{~mm}$ (Figure 1d), retention of sieve $6.0 \mathrm{~mm}$ (Figure 1e) and retention of sieve $6.5 \mathrm{~mm}$ (Figure 1f) a descriptive analysis was performed. It was verified that the productivity and the mass of thousand seeds (Figures 1a and 1b) show similar trends, since the magnitudes were similar when desiccation is carried out from the phenological stage R7.1, this agreement of the results is attributed to the dependence of the mass of one thousand seeds in the productivity, being this one of the main components of the soybean productivity (Lamego et al., 2013).

It was possible to verify the stability of the productivity from the desiccation carried out in the phenological stage R7.1 because the soybean seeds already reached the physiological maturity and accumulated the maximum amounts of dry matter, with this the application of desiccants does not directly influence the productivity and the mass of one thousand soybean seeds (Pereira et al., 2015; Nardino et al., 2016).

Regarding the retention of the 5.0 and $5.5 \mathrm{~mm}$ sieves (Figures $1 \mathrm{c}$ and $1 \mathrm{~d}$ ), the retention of these characters was verified when the desiccation was carried out at phenological stage R5.5. This behavior was determined because desiccation occurred before the point of physiological maturity, in this context, did not reveal the maximum accumulation of reserves that indirectly reflected in the reduction of seed size.

The use of desiccant products can standardize the plants for mechanized harvest, however, when the application occurs in the phases of division, expansion, deposition of reserves or adjustment of membranes, it can reduce the magnitude of allocated reserves, minimizing seed mass, productivity and physiological quality (Aumonde et al., 2017). 

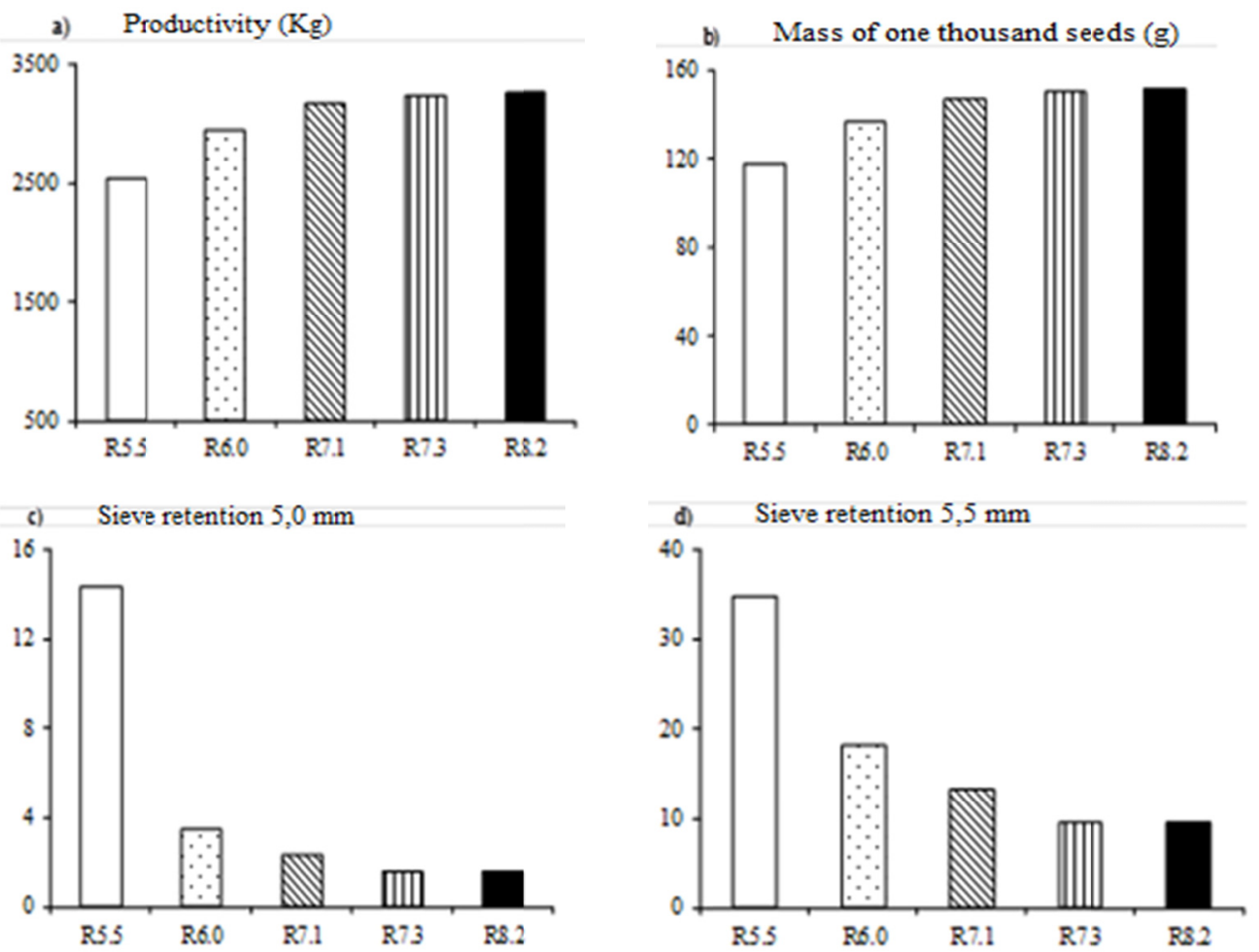

e) Sieve retention $6,0 \mathrm{~mm}$

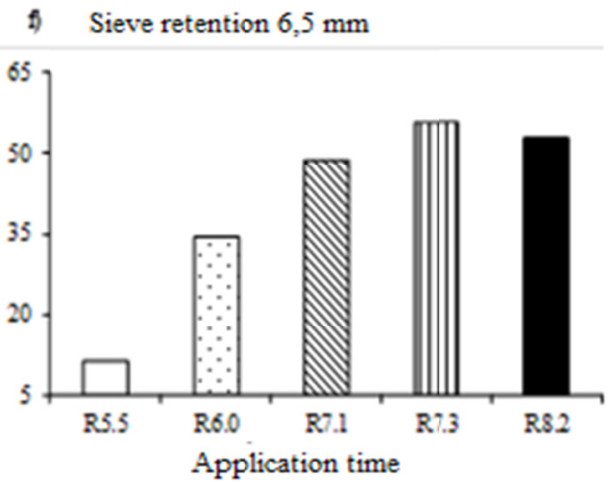

Figure 1. Graphs related to the descriptive analysis for the characteristics productivity, mass of one thousand seeds and retention of soybean seeds in the sieves 5.0, 5.5, 6.0 and $6.5 \mathrm{~mm}$, isolated for each phenological stage of desiccation (R5.5, R6.0, R7.1, R7.3 and R8.2)

The smaller diameter of the seeds was accentuated in seeds from the desiccation at the phenological stage R5.5, R6.0 and R7.1, in contrast, larger seed sizes were obtained when the desiccation was carried out at the phenological stages R7.3 and R8.2. This result may be related to the influence of the desiccant on the deposition of the reserves, where there are smaller seeds and with inadequate formation, these attributes being directly dependent on the maintenance of the photosynthetically active leaf area that captures the light energy and fixes the necessary amount of carbon through the photosynthesis, in this way, it is sought to maximize the accumulation of seed reserves by maintaining the leaf area of the plant to allocate the assimilated in the seeds and obtain superiority to the physiological attributes (Lopes \& Lima, 2015).

The highest retention of seeds was verified in the sieve $6.0 \mathrm{~mm}$ when the soybean was desiccated in the phenological stages R5.5 and R6.0 (Figure 1e). These oscillations identified in the maturation of the seeds are due to the unevenness among plants and in the plant itself, this is commonly observed in genotypes with an indeterminate growth habit, these results being attributed to the fact that some seeds did not fully reach phase II during the stage of seed development, this phase being responsible for the greater accumulation of dry matter (Marcos Filho, 2015). 
Regarding the retention in the $6.5 \mathrm{~mm}$ sieve, higher magnitudes were observed when desiccation was performed in the phenological stages R7.3 and R8.2 (Figure 1f). This fact determines that the desiccations carried out at these stages can increase the seed size and indirectly reflect on seeds of greater mass, a behavior verified by the mass of a thousand seeds character (Figure 1b) and consequently productivity (Figure 1a).

The analysis of variance showed significant interaction at $5 \%$ of probability between the phenological stages of desiccation $\times$ post-harvest storage times for the percentages of germinated seeds and percentage of abnormal seedlings (Figure 2, Table 1). For the percentage of germinated seeds, it was possible to identify similar trends for the desiccations carried out at the phenological stages R.5.5 and R.8.2, which obtained better adjustment to the cubic degree of the polynomial to represent the phenomenon, but with different magnitudes. Regarding the desiccation carried out at the phenological stage R6.0, the quadratic trend was identified along the storage time (Figure 2a).

Table 1. Dismemberment of the effects of the interaction for the qualitative factor (phenological stages) for the characteristics germination and percentage of abnormal seedlings in soybean seeds submitted to desiccation at the reproductive stages (R5.5, R6.0, R7.1, R7. 3 and R8.2)

\begin{tabular}{llllll}
\hline Germination (\%) & \multicolumn{5}{c}{ Reproductive stages } \\
\cline { 2 - 6 } Storage (days) & 5.5 & 6.0 & 7.1 & 7.3 & 8.2 \\
\hline 0 & $98 \mathrm{~A}$ & $97 \mathrm{~A}$ & $96 \mathrm{~A}$ & $97 \mathrm{~A}$ & $98 \mathrm{~A}$ \\
40 & $92 \mathrm{~B}$ & $95 \mathrm{~A}$ & $94 \mathrm{~A}$ & $94 \mathrm{~A}$ & $94 \mathrm{~A}$ \\
80 & $91 \mathrm{~B}$ & $93 \mathrm{~A}$ & $94 \mathrm{~A}$ & $93 \mathrm{~A}$ & $94 \mathrm{~A}$ \\
120 & $91 \mathrm{~B}$ & $94 \mathrm{~A}$ & $94 \mathrm{~A}$ & $94 \mathrm{~A}$ & $95 \mathrm{~A}$ \\
160 & $91 \mathrm{C}$ & $94 \mathrm{~A}$ & $93 \mathrm{~B}$ & $92 \mathrm{BC}$ & $94 \mathrm{AB}$ \\
\hline Anormal seedlings (\%) & \multicolumn{5}{c}{} \\
\hline \multirow{2}{*}{ Storage (days) } & 5.5 & 6.0 & 7.1 & 7.3 & 8.2 \\
\hline 0 & $2 \mathrm{~A}$ & $2 \mathrm{~A}$ & $2 \mathrm{~A}$ & $2 \mathrm{~A}$ & $1 \mathrm{~A}$ \\
40 & $7 \mathrm{~A}$ & $4 \mathrm{~B}$ & $4 \mathrm{~B}$ & $3 \mathrm{~B}$ & $4 \mathrm{~B}$ \\
80 & $7 \mathrm{~A}$ & $5 \mathrm{~B}$ & $4 \mathrm{BC}$ & $4 \mathrm{BC}$ & $3 \mathrm{C}$ \\
120 & $7 \mathrm{~A}$ & $4 \mathrm{~B}$ & $5 \mathrm{~B}$ & $3 \mathrm{~B}$ & $4 \mathrm{~B}$ \\
160 & $7 \mathrm{~A}$ & $4 \mathrm{~B}$ & $5 \mathrm{AB}$ & $5 \mathrm{AB}$ & $5 \mathrm{AB}$ \\
\hline
\end{tabular}

Note. * Means followed by the same lowercase letter in the line do not differ statistically from each other by the tukey test at $5 \%$ of probability.

When considering the desiccation carried out in the phenological stages R7.1 and R7.3, a linear reduction of the percentage of seeds germination was observed along the storage time (Figure 2a). In this context, seeds from soybean plants desiccated at more advanced reproductive stages presented higher magnitudes for germination percentage, in relation to the desiccation carried out in the phenological stages R6.0, R7.1 and R7.2, research confirms the results obtained and they define that in these stages there is compromise in the germination of soybean seeds (Kappes et al., 2009; Ferrari et al., 2016). In general, the use of pre-harvest desiccation herbicides focused on seed production practices results in negative effects to the percentage of germinated seeds and attributes that there is variation between the tested genotypes and the desiccant herbicide (Delgado et al., 2015; Botelho et al., 2016). 

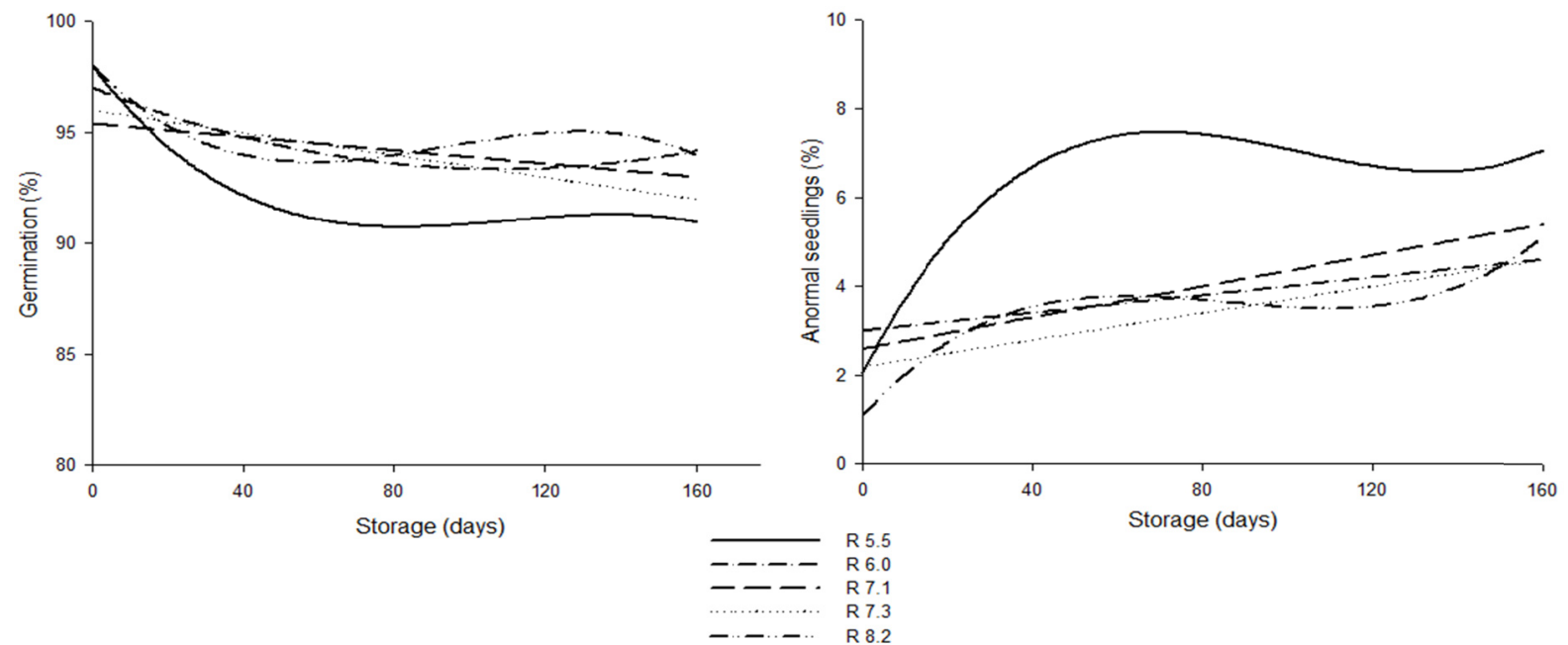

\begin{tabular}{|c|c|c|}
\hline \multirow{5}{*}{ Germination (A) } & R. 5.5 & $y=0.977-0.002 x+0.00002 x^{2}-0.00000007 x^{3}$ \\
\hline & R. 6.0 & $y=0.974-0.0007 x+0.000004 x^{2}$ \\
\hline & R. 7.1 & $\mathrm{y}=0.959-0.0002$ \\
\hline & R. 7.3 & $y=0.956-0.0003 x$ \\
\hline & R. 8.2 & $y=0.980-0.0002 x+0.00002 x^{2}-0.000000008 x^{3}$ \\
\hline \multirow{5}{*}{ Abnormal seedlings (B) } & R. 5.5 & $y=0.022+0.002 x-0.00002 x^{2}+0.00000006 x^{3}$ \\
\hline & R. 6.0 & $\mathrm{y}=0.030+0.0001 x$ \\
\hline & R. 7.1 & $y=0.031+0.0002 x$ \\
\hline & R. 7.3 & $y=0.020+0.00020 x$ \\
\hline & R. 8.2 & $y=0.012+0.001 x-0.00002 x^{2}+0.00000006 x^{3}$ \\
\hline
\end{tabular}

Figure 2. Dismemberment of the interaction effects to the quantitative factor (seed storage period) $(0 ; 40 ; 80$; 120 and 160 days after harvesting) before the phenological stages (R5.5, R6.0, R7.1, R7.3 and R8.2) of soybean

The percentage of abnormal seedlings showed for all the phenological stages of desiccation an increase in the magnitude of the character throughout the storage time, evidencing that the early dessections reduce not only the percentage of germinated seeds, as evidenced by the higher percentage of abnormal seedlings (Figure 2b). In this context, it is defined that the phenological stage R5.5 is inadequate for pre-harvest desiccation, aiming the production of high performance seeds.

The characteristics seedling field emergence and accelerated aging did not show any differential effects between the phenological stages where the desiccations were carried out with storage times. In this context, it is assumed that the expected responses to these characteristics show general effects regardless of the level of treatment (Table 2).

Table 2. Principal effects for field emergence and accelerated aging of soybean seeds submitted to desiccation at the reproductive stages (R5.5, R6.0, R7.1, R7.3 and R8.2)

\begin{tabular}{lll}
\hline Reproductive stages & Field emergence & Accelerated aging \\
\hline R5.5 & $89 \mathrm{c}$ & $92 \mathrm{~b}$ \\
R6 & $91 \mathrm{bc}$ & $93 \mathrm{ab}$ \\
R7.1 & $91 \mathrm{bc}$ & $93 \mathrm{ab}$ \\
R7.3 & $91 \mathrm{bc}$ & $93 \mathrm{ab}$ \\
R8.2 & $93 \mathrm{a}$ & $94 \mathrm{a}$ \\
\hline
\end{tabular}

Note. Means followed by the same lowercase letter in the line do not differ statistically from each other by the tukey test at $5 \%$ of probability.

In relation to the vigor test of the seeds represented by the emergence of the seedlings in the field, it was observed superiority for seeds from dried plants at the phenological stage R8.2, the other stages did not differ statistically. In relation to accelerated aging, the results show a similar trend and demonstrate evidence and 
positive effects when pre-harvest desiccation was performed late (R8.2). Research by Lacerda et al. (2003) did not show significant effects on vigor in seeds from dried plants at different reproductive stages.

When observing the general field emergence and accelerated aging performance in the soybean seeds, it is verified that, regardless of the phenological stage, the vigor of the seeds decreases sharply as the storage time advances. The differential response of stored seed vigor may be due to the period between physiological maturity and seed harvest, these oscillations in the response can be due to the intrinsic characteristics of the genotype, the conditions imposed on the seeds in the field of production, harvesting practices and processing and storage operations (Marcandalli et al., 2011).

In this way, it is evident that the application of the defoliant based on the paraquat molecule applied in soybean plants that are evidenced in the phenological stages previous to the physiological maturity of the seeds results in the compromise of the formation and development of the seeds, being able to compromise the physical and physiological quality during storage, as well as the mass of one thousand seeds and productivity.

\section{Conclusions}

The application of the Paraquat molecule in soybean plants in the phenological stages R5.5 and R6.0 compromises the physical attributes, mass of a thousand seeds and productivity.

Germination and vigor of soybean seeds are adversely affected by early desiccation of the plants, these effects are potentiated with the increase of seeds storage period.

Desiccation in the stages R7.1 and R7.3 does not affect yield, mass of a thousand seeds and physical attributes, however, it has negative effect on vigor, which is verified by the emergency at field.

\section{Acknowledgements}

The authors thank Capes and CNPq for their financial support.

\section{References}

Albrecht, L. P., Barbosa, A. P., Silva, A, F. M., Mendes, M. A., Albrecht, A, J. P., \& Avila, M. R. R. R. (2012). Soybean seed quality after application of glyphosate in different stages of development. Revista Braileira de Sementes, 34(3), 373-381. https://doi.org/10.1590/S0101-31222012000300003

Aumonde, T. Z., Pedo, T., Martinazzo, E. G., \& Villela, F. A. (2017). Estresses ambientais e a produção de sementes: Ciência e aplicação. Cópias Santa Cruz (p. 313). Pelotas, Brazil.

Botelho, F. J. E., Oliveira, J. A., Von Pinho, E. V. R., Carvalho, E. R., Figueiredo, I. B. D., \& Andrade, V. (2016). Qualidade de sementes de soja obtidas de diferentes cultivares submetidas à dessecação com diferentes herbicidas e épocas de aplicação. Revista Agro@mbiente On-line, 10(2), 137-144. https://doi.org/ 10.18227/1982-8470ragro.v10i2.2760

Brasil. (2009). Ministério da Agricultura, Pecuária e Abastecimento. Regras para análise de sementes (p. 395). Brasília, Brazil. Retrieved from http://www.agricultura.gov.br/assuntos/insumos-agropecuarios/arquivospublicacoes-insumos/2946_regras_analise_sementes.pdf

Carvalho, I. R., Nardino, M., Demari, G. H., Szareski, V. J., Follmann, D. N., Pelegrin, A. J., ... Souza, V. Q. (2017). Relations among phenotypic traits of soybean pods and growth habit. African Journal of Agricultural Research, 12(6), 450-458. https://doi.org/10.5897/AJAR2016.11660

Castro, E. M., Oliveira, J. A., Lima, A. E., Santos, H. O., \& Barbosa, J. I. L. (2016). Physiological quality of soybean seeds produced under artificial rain in the pre-harvesting period. Journal of Seed Science, 38(1), 14-21. https://doi.org/10.1590/2317-1545v38n1154236

CONAB (Companhia Nacional de Abastecimento). (2017). Acompanhamento da Safra Basileira de grãos (Vol. 4, No. 1, p. 118), Brasília: CONAB. Retrieved from http://www.conab.gov.br/OlalaCMS/uploads/arquivos/ 17_04_12_14_08_06_relatorio_safra_graos_rn_2017_7o_lev.pdf

Delgado, C. M. L., Coelho, C. M. M., \& Buba, G. P. (2015). Mobilization of reserves and vigor of soybean seeds under desiccation with glufosinate ammonium. Journal of Seed Science, 37(2), 154-161. https://doi.org/ $10.1590 / 2317-1545 \mathrm{v} 37 \mathrm{n} 2148445$

Ferrari, M., Pelegrin, A. J., Nardino, M., Carvalho, I. R., Szareski, V. J., Olivoto, T., ... Souza, V. Q. (2016). Evaluation of soybeans genotypes in field environments of Rio Grande do Sul state, Brazil. International Journal of Current Research, 8(9), 38383-38392. 
Follmann, D. N., Cargnelutti Filho, A., Souza, V. Q., Nardino, M., Carvalho, I. R., Demari, G., ... Szareeski, V. J. (2017). Relações lineares entre caracteres de soja safrinha. Revista de Ciências Agrárias (Lisboa), 40(1), 213-221. https://doi.org/10.19084/RCA16027

Forti, V. A., Carvalho, C., Tanaka, F. A. O., \& Cicero, S. M. (2013). Weathering damage in soybean seeds: Assessment, seed anatomy and seed physiological potential. Seed Technology, 35(2), 213-224. Retrieved from http://www.jstor.org/stable/24642271

Guimarães, V. F., Hollmann, M. J., Fioreze, S. L., Echer, M. M., Rodrigues-Costa, A. C. P., \& Andreotti, M. (2012). Produtividade e qualidade de sementes de soja em função de estádios de dessecação e herbicidas. Planta Daninha, 30(3), 567-573. https://doi.org/10.1590/S0100-83582012000300012

Kappes, C., Carvalho, M. A. C., \& Yamashita, O. M. (2009). Potencial fisiológico de sementes de soja dessecadas com diquat e paraquat. Scientia Agraria, 10(1), 001-006. https://doi.org/10.5380/rsa.v10i1. 12520

Kehl, K., Kehl, K., Aisenberg, G. R., Koch, F., Monteiro, M. A., Szareski, V. J., ... Aumonde, T. Z. (2016). Plant pre harvest desiccation and phisiological performance of wheat seeds before and after storage. International Journal of Current Research, 8, 38456-38460. Retrieved from http://www.journalcra.com/article/plant-preharvest-desiccation-and-physiological-performance-wheat-seeds-and-after-storage

Lacerda, A. L. S. Souzalazarini, A. L. D., Sá, E., Filho, M. E. D., \& Veriano, W. (2003). Armazenamento de sementes de soja dessecadas e Avaliação da qualidade fisiológica, bioquímica e sanitária. Revista Brasileira de Sementes, 25(2), 97-105. https://doi.org/10.1590/S0101-31222003000400014

Lamego, F. P., Gallon, M., Basso, C. J., Kulczynski, S. M., Ruchel, Q., Kaspary, T. E., \& Santi, A. L. (2013). Dessecação pré colheita e efeitos sobre a produtividade e qualidade fisiológica de sementes. Planta Daninha, 31(1), 929-938. https://doi.org/10.1590/S0100-83582013000400019.

Lopes, N. F., \& Lima, M. G. S. (2015). Fisiologia da produção (p. 485). Universidade Federal de Viçosa.

Marcandalli, L. H., Lazarini, E., \& Malaspina, I. G. (2011). Épocas de aplicação de dessecantes na cultura da soja: Qualidade fisiológica de sementes. R. Bras. Sementes, 33(2), 241-250. https://doi.org/10.1590/ S0101-31222011000200006

Marcos Filho, J. (1994). Teste de envelhecimento acelerado. In R. D. Vieira, \& N. M. Carvalho (Eds.), Testes de vigor em sementes (pp. 133-149). Jaboticabal: FUNEP.

Marcos-Filho, J. (2015). Fisiologia de Sementes de Plantas Cultivadas (2nd ed., p. 660). ABRATES, Londrina, PR, Brazil.

Mathias, V., Pereira, T., Mantovani, A., Zílio, M., Miotto, P., Coelho, M., \& Maria, C. (2017). Implicações da época de colheita sobre a qualidade fisiológica de sementes de soja. Agro@ambiente On-line, 11, 223-231. https://doi.org/10.18227/1982-8470ragro.v11i3.3894

Nardino, M., Carvalho, I. R., Demari, G. H., Pelissari, G., Pelegrin, A. J., Ferrari, M., ... Souza, V. Q. (2016). Components of variance, linear and canonical correlation soybean cultivars. Australian Journal of Basic and Applied Sciences, 10(10), 202-208.

Pereira, T., Coelho, C. M. M., Sobiecki, M., \& Souza, C. A. (2015). Physiological quality of soybean seeds depending on the preharvest desiccation. Planta Daninha, 33(3), 441-450. https://doi.org/10.1590/ S0100-83582015000300007

Pereira, T., Coelho, C. M. M., Souza, C. A., Mantovani, A., \& Mathias, V. (2015). Dessecação química para antecipação de colheita em cultivares de soja. Semina: Ciências Agrárias, 36(4), 2383-2394. https://doi.org/ 105433/1679-0359.2015v36n4p2383

Peske, S. T., Villela, F. A., \& Meneghello, G. E. (2012). Sementes: Fundamentos Científicos e Tecnológicos (3rd ed., p. 573). Pelotas, Brazil.

Rigo, G. A., Schuch, L. O. B., Vargas, R. L., Barros, W. S., Szareski, V. J., Carvalho, I. R., ... Pedo, T. (2018). Micronutrient Content and Physiological Quality of Soybean Seeds. Journal of Agricultural Science, 10(4), 223-230. https://doi.org/10.5539/jas.v10n4p223

Sedyama, T. (2013). Tecnologia e produção de sementes de soja (p. 352). Londrina: Mecenas. 
Silva-Xavier, T. D. A., Daronch, D. J., Peluzio, J. M., Afférri, F. S., De Carvalho, E. V., \& Dos Santos, W. F. (2015). Época de colheita na qualidade de sementes de genótipos de soja. Comunicata Scientiae, 6(2), 241-245. Retrieved from https://www.comunicatascientiae.com.br/comunicata/article/download/752/323

Szareski, V. J., Carvalho, I. R., Kehl, K., Levien, A. M., Nardino, M., Demari, G., ... Aumonde, T. Z. (2017).Univariate, multivariate techniques and mixed models applied to the adaptability and stability of wheat in the Rio Grande do Sul State. Genetics and Molecular Research, 16(3), 1-13. https://doi.org/ $10.4238 / \mathrm{gmr} 16039735$

Szareski, V. J., Carvalho, I. R., Nardino, M., Demari, G. H., Bahry, C. A., Kehl, K., ... Aumonde, T. Z. (2016). Phenotype stability of soybean genotypes for characters related to the physiological quality of seeds produced under different environmentall conditions. Australian Journal of Basic and Applied Sciences, $10(15), 279-289$.

Szareski, V. J., Zanatta, E., Koch, F., Aisenberg, G. R., Demari, G., Kehl, K., ... Aumonde, T. Z. (2016). Pre-harvest desiccation and seed production in soybean crops. International Journal of Current Research, $8(11), 41534-41537$.

Vargas, R. L., Schuch, L. O. B., Barros, W. S., Rigo, G. A., Szareski, V. J., Carvalho, I. R., ... Pedo, T. (2018). Macronutrients and Micronutrients Variability in Soybean Seeds. Journal of Agricultural Science, 10(4), 209-222. https://doi.org/10.5539/jas.v10n4p209

\section{Copyrights}

Copyright for this article is retained by the author(s), with first publication rights granted to the journal.

This is an open-access article distributed under the terms and conditions of the Creative Commons Attribution license (http://creativecommons.org/licenses/by/4.0/). 